\title{
Can we manipulate root system architecture to control soil erosion?
}

\author{
A. Ola, I. C. Dodd, and J. N. Quinton \\ Lancaster Environment Centre, Lancaster University, Lancaster LA1 4YQ, UK \\ Correspondence to: J. N. Quinton (j.quinton@lancaster.ac.uk)
}

Received: 21 January 2015 - Published in SOIL Discuss.: 26 March 2015

Revised: 4 August 2015 - Accepted: 5 August 2015 - Published: 8 September 2015

\begin{abstract}
Soil erosion is a major threat to soil functioning. The use of vegetation to control erosion has long been a topic for research. Much of this research has focused on the above-ground properties of plants, demonstrating the important role that canopy structure and cover plays in the reduction of water erosion processes. Less attention has been paid to plant roots. Plant roots are a crucial yet under-researched factor for reducing water erosion through their ability to alter soil properties, such as aggregate stability, hydraulic function and shear strength. However, there have been few attempts to specifically manipulate plant root system properties to reduce soil erosion. Therefore, this review aims to explore the effects that plant roots have on soil erosion and hydrological processes, and how plant root architecture might be manipulated to enhance its erosion control properties. We demonstrate the importance of root system architecture for the control of soil erosion. We also show that some plant species respond to nutrient-enriched patches by increasing lateral root proliferation. The erosional response to root proliferation will depend upon its location: at the soil surface dense mats of roots may reduce soil erodibility but block soil pores thereby limiting infiltration, enhancing runoff. Additionally, in nutrient-deprived regions, root hair development may be stimulated and larger amounts of root exudates released, thereby improving aggregate stability and decreasing erodibility. Utilizing nutrient placement at specific depths may represent a potentially new, easily implemented, management strategy on nutrient-poor agricultural land or constructed slopes to control erosion, and further research in this area is needed.
\end{abstract}

\section{Introduction}

Soil is a vital component of the earth system fundamental for many aspects of science (Brevik et al., 2015). The damage caused to soils by soil erosion is therefore of considerable concern. Soil erosion by water is a serious environmental problem representing a much greater threat to agricultural production than soil erosion by wind (Lal, 2010). Approximately 430 million hectares of arable land, or $30 \%$ of the globally available land for agricultural production, has been degraded by water erosion and a further $56 \%$ is at risk (Jankauskas et al., 2008). The effect of vegetation on reducing soil erosion is well known. Plants intercept rainfall; some is stored in the canopy with the remainder evaporating or reaching the soil surface either directly as throughfall, or indirectly through stem flow or leaf drainage (Stocking and Elwell, 1976; Puigdefábregas, 2005). Water reach- ing the soil surface may be stored in small depressions on the soil surface or infiltrate into the soil. The remainder may move downhill as overland flow, entraining soil particles and transporting them, and may also concentrate to form rills and gullies. There are a number of factors controlling erosion, namely the erosivity of the eroding agent, slope angle, the nature of the plant cover and the erodibility of the soil (Morgan, 1986). Erosion may result in on-site soil degradation reducing the soil's productivity and water storage capacity, due to changes in soil structure, soil depth and losses of nutrients and organic matter (OM). This may lead to significant losses of crop yield (Lal, 2001; Pimentel, 2006; Jankauskas et al., 2008), posing a threat to food security or limiting the production of renewable biotic resources (Pimentel, 2006; Jankauskas et al., 2008). Off-site problems associated with downstream sedimentation include flooding, pollution, negative effects on biodiversity, as well as the loss of reservoir 
storage (Pimentel and Kounang, 1998; Lal, 2001; Pimentel, 2006). In the UK, the annual costs of both on-site and off-site problems were recently estimated to range between GBP 248 and 469 million (Posthumus et al., 2013). Hence, there is a need to stabilize soils and preserve this crucial resource.

The importance of vegetation cover to control erosion has been demonstrated by many studies, from plot (Quinton et al., 1997) to basin scale (Zhao et at., 2013); it plays a significant role in the recovery of degraded land following anthropogenic and climatic stress (Cerdà and Doerr, 2005; Zhao et at., 2013). Both linear and exponential decreases in erosion rates associated with vegetation cover have been observed, as the nature of the relationship varies for canopy and ground covers, or inter-rill and rill erosion (Boer and Puidgefábregas, 2005). In Montana and Utah, for example, overland flow erosion rates increased ca. 200 times in response to a decrease in ground cover from $100 \%$ to less than $1 \%$ (Trimble and Mendel, 1995). A minimum of $10 \%$ plant cover was required to significantly reduce erosion rates on a semiarid hillslope in Arizona (Abrahams et al., 1988); however, the magnitude of the response ultimately depends on vegetation type and species (Bochet et al., 2006). Positive effects of the aerial biomass in controlling erosion are generally attributed to reductions in the kinetic energy of raindrops and reduced overland flow velocities (Stocking and Elwell, 1976; Puigdefábregas, 2005). Furthermore, vegetation covers modify intrinsic soil properties determining a soil's erodibility (Gyssels et al., 2005) creating a microclimate and supplying $\mathrm{OM}$, which affect the activity of microorganisms, and therefore nutrient availability, resulting in a positive feedback on plant productivity. Both additional $\mathrm{OM}$ as well as microbial and fungal secretions enhance the formation of stable aggregates (Boer and Puidgefábregas, 2005, Vásquez-Méndez et al., 2010), which affect hydraulic conductivity and, hence, water storage capacity (Boer and Puidgefábregas, 2005) and may increase soil shear strength (Tengbeh, 1993; De Baets et al., 2008).

Compared to studies on above-ground plant properties and soil erosion, the effects of below-ground biomass have received relatively little attention. However, it is clear that the reduction in soil loss due to vegetation results from the combined effects of the above- and below-ground biomass (Gyssels and Poesen, 2003). Concentrated flow erosion rates were reduced to almost zero within the $0-10 \%$ soil cross-sectional occupation by grass roots, but decreased only by $25-50 \%$ for the same increase in aerial cover (De Baets et al., 2006). Furthermore, a rainfall simulation experiment conducted 27 weeks after ryegrass (Lolium perenne) was sown in erosion pans demonstrated (by removal of the above-ground material) that the below-ground material of this species accounted for $90 \%$ of the decrease in soil detachment (Zhou and Shangguan, 2007).

In this paper we take an interdisciplinary view of the plant root and its interaction with the soil, and review the literature concerning the effects of roots on soil properties determining the resistance of soil to water erosion (concentrated and sheet flow) with emphasis on root system architecture (RSA). We then explore the factors influencing RSA especially lateral root (LR) growth, and finally the potential of fertilizer applications to stimulate LR proliferation, and thus form the basis for a soil erosion control method, will be discussed.

\section{The effects of roots on soil erodibility}

Erodibility is the result of various mechanical, adhesive and cohesive bonding forces acting within the soil matrix (Knapen et al., 2007) and should be regarded as a "summation of a highly complex response pattern, strongly influenced by intrinsic soil characteristics and extrinsic variables" (Bryan, 2000). The erosion response may be influenced by any soil property, but will be dominated by shear strength, aggregate stability and hydraulic function (Bryan, 2000). Roots alter the erodibility of a soil through their effect on these soil properties in a number of ways (Fig. 1). Firstly, roots have a high tensile strength (Gyssels et al., 2005; De Baets et al., 2008) providing up to $100 \%$ of the cohesive strength of a root permeated soil (Hales et al., 2009), thus increasing soil shear strength. The additional tensile strength associated with roots is responsible for the transfer of shear stresses via tensile resistance or interface friction within the soil-root matrix (Prosser et al., 1995; De Baets et al., 2008). There was a positive linear relationship between the crosssectional area of barley (Hordeum vulgare) roots at the shear plane and subsequent increases in soil shear strength in a silty clay loam soil (Waldron, 1977). In ryegrass, increasing root densities from 0.20 to $1.80 \mathrm{~g} \mathrm{~cm}^{-3}$ also increased strength from 1 to $5 \mathrm{kPa}$ in a sandy clay loam (Tengbeh, 1993). Hence, the presence of roots considerably increases shear strength.

Secondly, roots prevent sediment transport by retaining soil particles (De Baets et al.,2006) and increasing the number of stable aggregates, due to their enmeshing effect (Haynes and Beare, 1997), which is also true for fungal hyphae (Haynes and Beare, 1997; Degens, 1997; MorenoEspíndola et al., 2007), and the release of various organic and inorganic binding agents (Amezketa, 1999). Root exudates such as mucilage are considered the main mechanism by which plant roots enhance aggregate stability (Morel et al., 1991; Moreno-Espíndola et al., 2007). Root mucilage expands under wet conditions covering soil particles, while subsequent drying leads to the contraction of mucilage, pulling these soil particles tightly together to form a rhizosheath, and thereby reorienting clay particles parallel to the axis of the root (Oades, 1984; Watt et al., 1994; Amezketa, 1999; McCully, 1999). Moreover, root exudates are associated with the release of polyvalent cations that form strong bonds between organic molecules and clays (Oades, 1984; Pojasok and Kay, 1990; Amezketa, 1999). Increasing amounts of ions in solution after exudates were added limit clay dispersion and significantly increase aggregate stability 


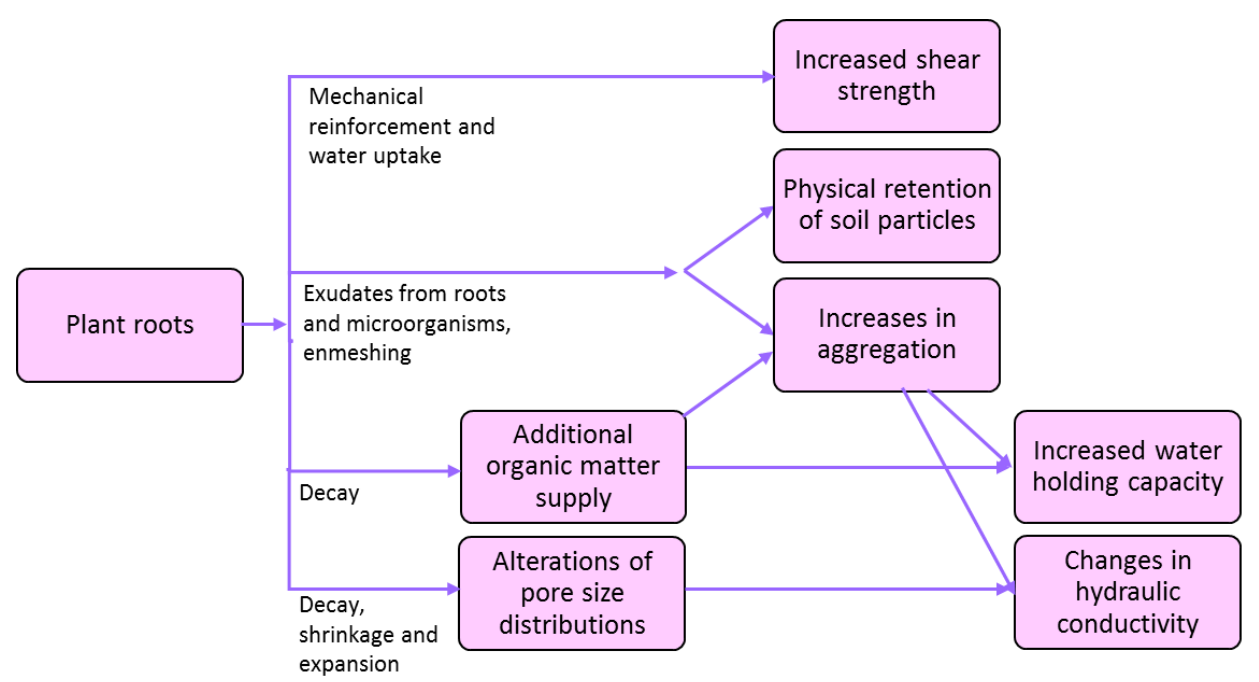

Figure 1. Key mechanisms by which plant roots influence soil physical properties.

(Pojasok and Kay, 1990). Decaying roots and fungal hyphae also represent a source of OM (Oades, 1984; Haynes and Beare, 1997; Amezketa, 1999) that contributes to aggregate stability. Thus aggregate stability is enhanced by biological activity (both plant and fungal) within the soil.

Root exudates represent 5 to $21 \%$ of a plant's photosynthetically fixed carbon (C) (Walker et al., 2003) serving as a crucial energy source for microorganisms (Haynes and Beare, 1997; Amezketa, 1999). Both fungal and bacterial extracellular polymeric substances contribute to the cementation of aggregates and, thus, enhance aggregate persistence (Oades, 1984; Morel et al., 1991; Watt et al., 1994; Haynes and Beare, 1997; Bryan, 2000). However, the effect of roots on aggregate stability is species specific (Haynes and Beare, 1997; Amezketa, 1999) due to differences in root morphology (Pohl et al., 2009), turnover rates (Stokes et al., 2009), the quantity and chemical composition of the root exudates and the influence of differences in root exudates on microbial activity (Haynes and Beare, 1997, Bertin et al., 2003). Barley roots increased aggregate stability (Haynes and Beare, 1997), whilst there is contradicting evidence about the effects of roots of maize (Zea mays). Root mucilage of maize reportedly increased aggregation (Morel et al., 1991), but the release of chelating agents, such as organic acids (which destroy iron and aluminium bonds with $\mathrm{OM}$ ) by maize, decreased aggregate stability (Oades, 1984). These contrasting results may be attributed to genotypic variation in the chemistry of the root exudates. For example, within different barley genotypes, three structural variations of mugineic acid (an organic ligand) have been found (Bertin et al., 2003). In addition, some organic compounds released by roots and microorganisms may also induce water repellency depending on soil matric potential and the number of wetting and drying cycles undergone (Hallett et al., 2003). However, OM and aggregate stability are crucial in the formation of macropores, which reduce bulk density and facilitate gaseous diffusion and improve infiltration rates (Gyssels and Poesen, 2003). Thus, the effects of root exudates vary between species and depend on their composition.

Roots may also provide soils with additional surface roughness enhancing infiltration rates (De Baets et al., 2006), while water uptake through roots (Macleod et al., 2007) and the creation of continuous pore spaces increase the infiltration capacity, reducing surface runoff (Bryan, 2000; Bronick and Lal, 2005; Macleod et al., 2007). Quinton et al. (2002) found a positive correlation between infiltration rates and root density for needle grass (Stipa tenacissima) and, to a lesser extent, for downy plantain (Plantago albicans), while unclear results were obtained for albaida (Anthyllis cytisoides) and white wormwood (Artemisia herba-alba). Under alfalfa (Medicago sativa), $60 \%$ of all flow paths are associated with the roots or the channels of decomposed roots allowing water to rapidly percolate through the soil matrix (Stokes et al., 2009). Shallow, fibrous root systems and rhizomatous mats of ryegrass and common bent grass (Agrostis capillaris), respectively, resulted in a low saturated hydraulic conductivity (Morgan et al., 1995). Several authors (Mitchell et al., 1995; Meek et al., 1989; Archer et al., 2002; Devitt and Smith, 2002) suggest that living roots occupy available macropores for flow pathways, and enhance infiltration rates over time, as a result of channels created by decaying roots. Infiltration rates in a sandy loam, for instance, tripled within 3 years of alfalfa cultivation (Meek et al., 1989), and significantly increased infiltration rates were recorded for the last half of the growing season, and after harvest, of a maize crop (Archer et al., 2002). This is also supported by observations that the root effect of ryegrass on increasing infiltration rates (thus decreasing runoff) increased with time (Zhou and Shangguan, 2007). Moreover, the effects associated with cyclic shrinking-expanding of roots in accordance 
with water availability also created flow pathways over time (Archer et al., 2002). However, the effect of roots on flow pathways, and thus infiltration rates, differed under a number of Mediterranean species, due to differences in root morphology (Quinton et al., 2002), and turnover rates, as a result of differences in root diameter and chemical composition (Stokes et al., 2009). Thus, not only the presence of roots but their physical arrangement within the soil alters soil hydraulic properties.

A frequently used root parameter that sufficiently describes the effectiveness of a species to control concentrated flow erosion rates (Burylo et al., 2012) is root length density (RLD). RLD is the total length of the roots divided by the volume of the root permeated soil sample (De Baets et al., 2006), thus providing information about the occupation of soil by roots (Bauhus and Messier, 1999; De Baets et al., 2006, De Baets et al., 2007). Under cereal and grass plants in the loess belt of Belgium, concentrated flow erosion rates exponentially decreased with a linear increase in RLD (Gyssels and Poesen, 2003). Similar results were obtained by Mamo and Bubenzer (2001a, b) between erosion rates of a silt loam soil subjected to concentrated flow and RLD in maize and soybean (Glycine max), which reduced detachment rates by $50 \%$ compared to fallow soils. A similar relation exists between RLD of barley and detachment rates (De Baets et al., 2006). However, increasing RLD either affects soil shear strength positively (Ghidey and Alberts, 1997; Mamo and Bubenzer, 2001a, b), or not at all, depending on species and soil type (Pierret et al., 2007). Furthermore, higher RLDs enhance soil aggregation in crop species (Haynes and Beare, 1997) and when comparing grass, forb and legume species from a natural grassland ecosystem (Rilling et al., 2002). However, the ability of roots to reinforce a soil is determined not only by root characteristics such as RLD but also by their distribution within the soil.

\section{Root system architecture and its manipulation}

RSA is the three-dimensional deployment of roots (Linkohr et al., 2002; Basu et al., 2011). In eudicots, RSA is mainly determined by the extent and direction of root tip growth and the positioning and frequency of LRs (Jones and Ljung, 2012). Therefore, in this review "manipulating RSA" refers to alterations being made to the spatial configuration of the roots of an individual plant in respect of LR growth (i.e. initiation, elongation, diameter, branching) by stimulating proliferation of these roots at certain depths. RSA is constitutively influenced by genetic factors (Smucker, 1993; Malamy, 2005; Stokes et al., 2009), as demonstrated by mutants of maize lacking different root classes (Malamy, 2005). Mature cereal root systems consist mostly of coarse (seminal - seed derived, or nodal - shoot derived) roots and fine (lateral) roots $(\varnothing<1 \mathrm{~mm})$ (LRs), which often develop root hairs (McCully, 1999) from the trichoblasts in the meristem- atic zone (Gilroy and Jones, 2000). Although LRs are the major sites of water and nutrient uptake, coarse roots are mainly responsible for anchorage, the storage of nutrients, water and $\mathrm{C}$, as well as the penetration of hard soils and deep horizons (Guerrero-Campo et al. 2006). LRs tend to have greater growth rates than other roots (Guerrero-Campo et al., 2006; Stokes et al., 2009) and account for ca. 90-98\% of the total root length of a root system (Engineer and Kranz, 2007; Pohl et al., 2009). Hence, total root length is mainly determined by the density of LRs (Guerrero-Campo et al., 2006; De Baets et al., 2007; Pierret et al., 2007). Thus RLD significantly increased with the percentage of LRs (Burylo et al., 2012), and decreased with increasing root diameters (Pohl et al., 2009).

Moreover, different types of root system are often distinguished based on the presence of a primary root representing a single dominant axis with varying degrees of LR development, which is characteristic for primary or tap root systems (Fitter, 1987), whereas root systems lacking a primary root are referred to as a fibrous root system (De Beats et al., 2007). Only a few studies have compared the effect of these different root systems on soil erosion rates, with fibrous root systems being more effective in reinforcing soils against concentrated flow than tap root systems with similar root mass (De Baets et al., 2007). In contrast, tap rooting species increase saturated hydraulic conductivity, which tends to be low under fibrous root systems (Archer et al., 2002; Quinton et al., 2002). These observations can be explained by the larger number of LRs and greater root length densities (RLD) associated with fibrous root systems compared to tap root systems (De Baets et al., 2007).

Macleod et al. (2007) propose specific genetic selection and breeding for root traits, such as rooting depth, to improve soil hydraulic function. However, these root traits are under complex genetic control (Zhu et al., 2005; Macleod et al., 2007) even though alleles determining, for example, LR primordia development in thale cress (Arabidopsis thaliana) (Roycewicz and Malamy, 2014), as well as LR branching or length in maize (Zhu et al., 2005), have been identified. Limited knowledge of the root phenome, the "chaotic" nature of the interactions among phenes and environmental factors, ultimately determining crop performance and function (Lynch and Brown, 2012), hinders the development of new crop varieties with altered root traits. Although RSA is genetically constrained, it is highly plastic in response to environmental cues. This means that genetically identical plants may differ in root density, growth rate, placement and growth direction (Müller and Schmidt, 2004; Malamy, 2005), as a result of adaptive responses (López-Bucio et al., 2003; Jones and Ljung, 2012) to the prevailing environmental conditions. The heterogeneous distribution of nutrients can increase LR length and initiation, as well as coordinate proliferation of LRs in soil regions where these resources are present (e.g. Fitter, 1987; Smucker, 1993; Stokes et al., 2009). Hence, the localized application of nutrients at prescribed depths and associated LR proliferation offers an opportunity to manipu- 
late LR distribution within the soil profile, thereby promoting RSAs that reduce soil erosion.

\section{Lateral root proliferation in response to local nutrient availability}

The local proliferation of LRs allows the optimal exploitation of locally available nutrient reserves (Smucker, 1993; Robinson, 1994; Hodge, 2006). Lack of nitrogen (N) as well as phosphorus (P) often limits growth (Linkohr et al., 2002; López-Bucio et al., 2003). Nitrate $\left(\mathrm{NO}_{3}^{-}\right)$is the major source of $\mathrm{N}$ for most plants and is, as well as ammonium $\left(\mathrm{NH}_{4}^{+}\right)$, readily available to plants (Engineer and Kranz, 2007). A series of studies by Drew and co-workers investigated the response of barley roots to local nutrient enrichment. Although a heterogeneous distribution of potassium (K) did not affect RSA (Drew, 1975; Robinson, 1994), LR initiation and extension increased within a $4 \mathrm{~cm}$ long segment of a seminal root exposed to 100 times greater concentrations of $\mathrm{NO}_{3}^{-}$and $\mathrm{NH}_{4}^{+}$than the remainder of the root system, where nutrientlimited conditions inhibited LR development (Drew et al., 1973; Drew, 1975; Drew and Saker, 1975) (Fig. 2). The same is true for wheat (Triticum aestivum) (Drew, 1975; Forde and Lorenzo, 2001) and maize grown in a flowing nutrient culture whereby two nodal roots exposed to different $\mathrm{NO}_{3}^{-}$concentrations revealed similar results (Granato and Raper, 1989). Furthermore, a concentration of $1 \mathrm{mM} \mathrm{NO}_{3}^{-}$stimulated LR branching and increased LR diameters in both maize and barley (Drew, 1975; Granato and Raper, 1989), possibly due to increases in stele diameter and the numbers of cells in the root cortex and stele (Forde and Lorenzo, 2001). When thale cress was grown on vertical agar plates with a $\mathrm{NO}_{3}^{-}$enriched band halfway down the plate, LR lengths increased 2-3 fold, although there was no evidence for enhanced LR initiation (Zhang and Forde, 1998). However, nutrient solutions containing $\mathrm{NH}_{4}^{+}$as primary $\mathrm{N}$ source lead to higher root densities and increased root elongation in maize compared to solutions containing $\mathrm{NO}_{3}^{-}$(Jing et al., 2010). The localized availability of $\mathrm{P}$ often also results in increased LR extension (Drew, 1975; Robinson, 1994) and sometimes increased LR initiation within this zone (Drew, 1975). However, Drew (1975) highlights the importance of the presence of both nutrients, $\mathrm{N}$ and $\mathrm{P}$, in stimulating LR proliferation. In addition, LR proliferation has been reported in response to organic and inorganic $\mathrm{N}$ and $\mathrm{P}$, although the response to the former is determined by the extent and rate in which mineralization has occurred (Robinson, 1994). Thus LR proliferation in response to localized nutrient patches is well documented in many species grown in different artificial (not soil) media.

Root proliferation is believed to be triggered partly by shoot-to-root signalling, as the developmental response to localized increased $\mathrm{NO}_{3}^{-}$was most pronounced with plants of low N status (Forde and Lorenzo, 2001; Forde, 2002). High $\mathrm{NO}_{3}^{-}$levels result in increased auxin concentration in the LR tip stimulating $\mathrm{LR}$ growth, while high $\mathrm{NH}_{4}^{+}$levels enhance higher-order root branching. The presence of both forms of $\mathrm{N}$ results in a complementary response (Forde, 2002; Jones and Ljung, 2012). However, if $\mathrm{NO}_{3}^{-}$concentrations are too high, LR growth tends to be inhibited (Zhang and Forde, 1998; Linkohr et al., 2002), which is mediated by abscisic acid (López-Bucio et al., 2003). A detailed discussion of the molecular mechanisms responsible for LR proliferation in nutrient-rich zones is beyond the scope of this paper, but the topic has been recently reviewed by Jones and Ljung (2012).

However, the growth media used in these studies (agar, hydroponics) do not necessarily reflect natural conditions and it is important to determine whether such responses occur in soil. Paradoxically, when wheat plants were grown in soilfilled rhizotrons (1.4 m deep) with nutrients (both $\mathrm{N}$ and $\mathrm{P}$ ) banded at $0-40$ or $60-100 \mathrm{~cm}$ below the soil surface and the soil allowed to dry (simulating a terminal drought stress), the greatest RLD detected at $1.4 \mathrm{~m}$ occurred with the surface fertilizer application (Jin et al., 2015). However, fertilizer banding (stratification) and local placement (patches) can elicit different responses. LRs of thale cress in a $\mathrm{NO}_{3}^{-}$-enriched patch in a heterogeneous soil were only marginally longer than in the corresponding patch under homogeneous conditions (Linkohr et al., 2002). Nevertheless, LR proliferation has been observed in the field (Sattelmacher et al., 1993; Robinson, 1994). A recent study in North China showed that banding $\mathrm{NH}_{4}^{+}$and $\mathrm{P}$ at $10 \mathrm{~cm}$ depth resulted in a $23-30 \%$ increase in total root length and higher RLD at a depth of 0 $15 \mathrm{~cm}$ in maize compared to broadcast application, or banding of $\mathrm{P}$ only while $\mathrm{NH}_{4}^{+}$was broadcast. Moreover, banding of both nutrients also increased RLD at a depth of 15$30 \mathrm{~cm}$ (Jing et al., 2010). However, the responsiveness of plants to localized nutrient availability varies between different species and genotypes (Robinson, 1994).

\section{Manipulating root system architecture with nutrient placement to control erosion}

Beyond the selection of different plant species, little consideration has been given to the potential of manipulating RSA for soil erosion control, despite it being known that the distribution of LRs within the top $50 \mathrm{~cm}$ of the soil is crucial in determining the effect of roots on the resistance of soils to concentrated flow erosion ( $\mathrm{Li}$ et al., 1991). Dense mats of LRs are commonly found at the soil surface (Pierret et al., 2007) and the abundance of roots gradually declines with increasing soil depth (Quinton et al., 2002; De Baets et al., 2008). However, it has been argued higher RLDs at deeper soil depths would be particularly beneficial, as this increases possible water uptake and evapotranspiration rates, thus infiltration rates (Stokes et al., 2009), and would provide reinforcement to deeper soil layers in situations where concentrated flow erosion is problematic. In addition, longer vertical roots, which increase RLD at depth, provide con- 
Control

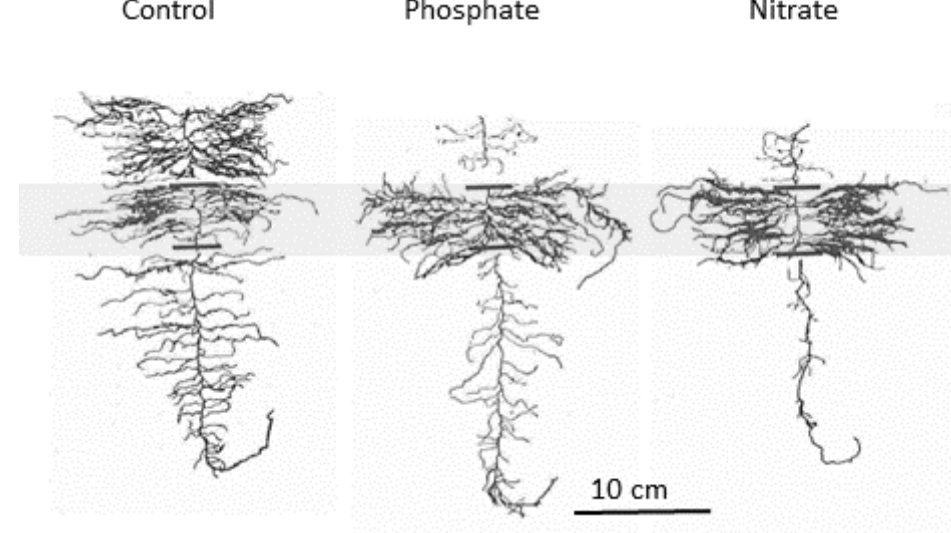

Ammonium

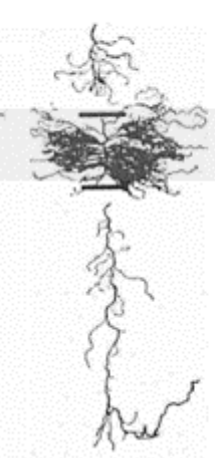

Potassium

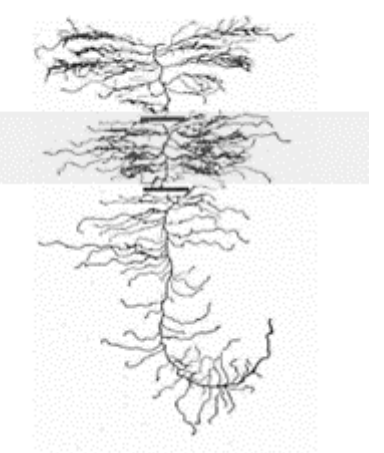

Figure 2. Effect of a localized supply of phosphate, nitrate, ammonium, and potassium on root form. Control plants received the complete nutrient solution to all parts of the root system. The other roots received the complete nutrient solution only in the middle zone (shaded), the top and bottom being supplied with a solution deficient in the specified nutrient. Adapted and reproduced with permission from Drew (1975)

() John Wiley and Sons.

duits to deeper soil layers (Archer et al., 2002; Devitt and Smith, 2002; Quinton et al., 2002) and directly affect water storage capacity of the effective soil depth (Macleod et al., 2007; Stokes et al., 2009). Improvements in aggregate stability tend to be particularly pronounced in, if not spatially limited to, the rhizosphere (Oades, 1994; Foster, 1988; Morel et al., 1991; Haynes and Beare, 1997), so the extent of the root system determines its effect on soil aggregation (Haynes and Beare, 1997). The effects of roots of the grasses Stipa bungeana and Bothriochloa ischaemum on the properties of a Chinese loess soil (soil organic matter and aggregate stability, especially in large diameter classes) decreased with increasing depth, as RLD diminished ( $\mathrm{Li}$ and $\mathrm{Li}, 2011)$. The higher sediment load derived from deep soil horizons associated with the higher susceptibility of these soil horizons to erosional forces was further enhanced by increasing runoff discharge and slope gradient ( $\mathrm{Li}$ and $\mathrm{Li}, 2011)$ and was particularly critical during concentrated flow erosion. Furthermore, soil cohesion provided by roots is also limited to the rooting depth of the vegetation; consequently, soil reinforcement decreases with increasing depth (Gyssels et al., 2005; De Baets et al., 2008). Although Mediterranean shrubs typically only stabilize the top $50 \mathrm{~cm}$ of gully walls and hillslopes, failures may occur at deeper depths and increases in soil strength depend on the number of LRs that cross the potential shear plane (Reubens et al., 2007; De Baets et al., 2008).

Plants may also respond to heterogeneous nutrient supply with compensatory root growth (Drew, 1975; Robinson, 1994). Compensatory growth means that proliferation within the $\mathrm{N}$ - or P-enriched zone compensates, and may be proportional to, the inhibitory effect of the limited availability of these nutrients on LR development outside this zone (Robinson, 1994). In this case, soil properties at different soil layers may change accordingly to the proportion of LRs present within these layers. Reduced LR growth on the soil surface, when nutrients are only available at deeper depths, could reduce resistance to surface erosion, but could potentially increase the water storage capacity of a soil, as the number of blocked pores by LRs at the soil surface would be reduced. Furthermore, although the diameter of LR increases in nutrient-enriched zones (Drew, 1975; Granato and Raper, 1989; Forde and Lorenzo, 2001), LR proliferation may still increase shear strength locally (De Baets et al., 2008; Loades et al., 2010) and could help to reinforce soils at the shear plane. In addition, aggregate stability may be improved within the nutrient-poor patch, as larger quantities of mucilage may be released within this zone to mobilize scarcely available P (Bertin et al., 2003). In contrast, Paterson et al. (2006) showed that LR proliferation in response to localized availability of $\mathrm{NO}_{3}^{-}$resulted only in a locally increased release of root exudates in barley. Compensatory growth may also enhance root hair development in the nutrient-poor zone, and root hairs contribute to soil aggregation in the rhizosphere and are crucial for rhizosheath development (Hochholdinger et al., 2004; Moreno-Espíndola et al., 2007). Root hair length increased from $0.1-0.2$ to $0.7 \mathrm{~mm}$ and density by a factor of 2-4 when spinach (Spinacia oleracea), tomato (Solanum lycopersicum) and rapeseed (Brassica napus) were grown in nutrient solutions with concentrations of $2 \mu \mathrm{M}$ P compared to concentrations of $1000 \mu \mathrm{M}$ $\mathrm{P}$ (Foehse and Jungk, 1983). Split-root system experiments demonstrated root hair development of spinach in high $\mathrm{P}$ concentrations is not affected if the remainder of the root system is exposed to low P concentrations. In contrast, the magnitude of the positive effect on root hair development of limited $\mathrm{NO}_{3}^{-}$varied between species. However, further research is needed into the effects of differences in LR growth dynamics in response to localized fertilizer application on soil properties and subsequently erosion rates. 


\section{Effects of LR proliferation on aerial growth}

LR proliferation is important for achieving high agricultural yields, but, as previously mentioned, it also plays a key role in controlling erosion. Recent estimates suggest root proliferation is a relatively low-cost strategy adapted by plants to effectively absorb available ions and water in heterogeneous environments, requiring only an additional $0.2 \%$ of the plant's daily $\mathrm{C}$ gain (Hodge, 2006). Only roots with small diameters proliferate (Drew, 1975; Granato and Raper, 1989; Smucker, 1993; McCully, 1999), as fine roots represent less resistance to the flow of ions and water during the uptake of these resources (Smucker, 1993). However, net C costs will be determined by factors such as rooting volume, photosynthetic supply and may be even zero if compensatory growth occurs (Robinson, 2001). This should buffer potential negative effects of limited nutrient availability within some soil areas on above-ground biomass, although biomass partitioning ultimately depends on shoot nutrient status (Drew, 1975; Drew and Saker, 1975; Robinson, 1994). LR proliferation either increases or has no effect on root to shoot ratios (Robinson, 1994). Shoot development may be slightly retarded, which is reflected in lower shoot biomass of barley grown under heterogeneous nutrient availability compared to the controls (Drew and Saker, 1975). This shoot growth inhibition was attributed to initial nutrient deficiencies until the roots reached the nutrient-rich zone (Drew and Saker, 1975). In addition, placement of $\mathrm{N}$ fertilizer (calcium ammonium nitrate) at $10 \mathrm{~cm}$ depth compared to surface mixing significantly increased dry matter production and grain yield at maturity of wheat grown in a loamy sand soil (Sharma and Chaudhary, 1983). However, there is a large variability between species (Robinson, 1994; Hodge, 2006) and genotypes (Sattelmacher et al., 1993; Forde and Lorenzo, 2001) in their shoot responsiveness, which depends on differences in nutrient uptake and utilization efficiency (Sattelmacher et al., 1993). Nevertheless, LR proliferation may occur without limiting above-ground growth (and yield).

\section{Conclusions}

In conclusion, plant roots are crucial in reducing soil erosion rates due to overland flow, as their presence affects soil properties such as aggregate stability, hydraulic function and shear strength. However, the effect of roots on soil erodibility is determined by RLD and, thus, LR density and length, and the distribution of roots within the soil. It has been argued that a higher RLD would be particularly beneficial in reducing soil erosion rates and that fertilizer placement may be one way of achieving this. In nutrient-poor soils, the local availability of high $\mathrm{N}$ or $\mathrm{P}$ may result in LR proliferation, although the response will depend on plant species, and may include a general increase in rooting depth or compensatory growth.
However, research is needed to determine whether the localized application of $\mathrm{N}$ and $\mathrm{P}$ at specific soil depths may represent a potential management technique to control erosion of degraded agricultural soils with low nutrient levels. Investigations should therefore aim to explore the effects of LR distribution at varying depths on soil properties and, hence, soil erodibility. Trade-offs between reduced erodibility due to LR proliferation and potential reductions in soil hydraulic conductivity need to be explored. In addition, responsiveness of different crops, grasses and shrubs (and different genotypes within a species) to heterogeneous nutrient availability should be determined. Moreover, suitable depth(s) for deep fertilizer placement should be established (with reference to practical implementation), and the effects of varying environmental conditions, such as soil type, slope and flow characteristics, on the erosion reducing effect of this potential management technique need to be assessed.

Edited by: A. Cerdà

\section{References}

Abrahams, A. D., Parsons, A. J., and Luk, S. H.: Hydrologic and sediment responses to simulated rainfall on desert hillslopes in southern Arizona, Catena, 15, 103-117, 1988.

Amezketa, E.: Soil aggregate stability: a review, J. Sustain. Agr., 14, 83-151, 1999.

Archer, N. A. L., Quinton, J. N., and Hess, T. M.: Below-ground relationships of soil texture, roots and hydraulic conductivity in two-phase mosaic vegetation in South-east Spain, J. Arid Environ., 52, 535-553, 2002.

Basu, P., Brown, K. M., and Pal, A.: Detailed Quantitative Analysis of Architectural Traits of Basal Roots of Young Seedlings of Bean in Response to Auxin and Ethylene, Plant Physiol., 155, 2056-2065, 2011.

Bauhus, J. and Messier, C.: Soil exploitation strategies of fine roots in different tree species of the southern boreal forest of eastern Canada, Can. J. Forest Res., 29, 260-273, 1999

Bertin, C., Yang, X., and Weston, L.: The role of root exudates and allelochemicals in the rhizosphere, Plant Soil, 256, 67-83, 2003.

Bochet, E., Poesen, J., and Rubio, J. L.: Runoff and soil loss under individual plants of a semi-arid Mediterranean shrubland: influence of plant morphology and rainfall intensity, Earth Surf. Proc. Landf., 31, 536-549, 2006.

Boer, M. and Puidgefábregas, J.: Effects of spatially structured vegetation patterns on hillslope erosion in a semiarid Mediterranean environment: a simulation study, Earth Surf. Proc. Landf., 30, 149-167, 2005.

Brevik, E. C., Cerdà, A., Mataix-Solera, J., Pereg, L., Quinton, J. N., Six, J., and Van Oost, K.: The interdisciplinary nature of SOIL, SOIL, 1, 117-129, doi:10.5194/soil-1-117-2015, 2015.

Bronick, C. J. and Lal, R.: Soil structure and management: a review, Geoderma, 124, 3-22, 2005.

Bryan, R. B.: Soil erodibility and processes of water erosion on hillslope, Geomorphology, 32, 385-415, 2000. 
Burylo, M., Rey, F., Mathys, N., and Dutoit, T.: Plant root traits affecting the resistance of soils to concentrated flow erosion, Earth Surf. Proc. Landf., 37, 1436-1470, 2012.

Cerdà, A. and Doerr, S.: The influence of vegetation recovery on soil hydrology and erodibility following fire: an eleven-year research, Int. J. Wildland Fire, 14, 423-437, 2005.

De Baets, S., Poesen, J., Gyssels, G., and Knapen, A.: Effects of grass roots on the erodibility of topsoil during concentrated flow, Geomorphology, 76, 54-67, 2006.

De Baets, S., Poesen, J., Knapen, A., and Galindo, P.: Impact of root architecture on the erosion-reducing potential of roots during concentrated flow, Earth Surf. Proc. Landf., 32, 1323-1345, 2007.

De Baets, S., Poesen, J., Reubens, B., Wemans, K., De Baerdemaeker, J., and Muys, B.: Tensile strength and root distribution of typical mediterranean plant species and their contribution to soil shear strength, Plant Soil, 305, 207-226, 2008.

Degens, B. P.: Macro-aggregation of soils by biological bonding and binding mechanisms and the factors affecting these: A review, Austr. J. Soil Res., 35, 431-459, 1997.

Devitt, D. A. and Smith, S. D.: Root channel macropores enhance downward movement of water in a Mojave Desert ecosystem, J. Arid Environ., 50, 99-108, 2002.

Di Tomaso, J. M.: Approaches for Improving Crop Competitiveness through the Manipulation of Fertilization Strategies, Weed Science, 43, 491-497, 1995.

Drew, M. C.: Comparison of the effects of a localized supply of phosphate, nitrate, ammonium and potassium on the growth of the seminal root system, and the shoot, in barley, New Phytologist, 75, 479-490, 1975.

Drew, M. C. and Saker, L. R.: Nutrient supply and the growth of the seminal root system of barley. II. Localized, compensatory increases in lateral root growth and rates of nitrate uptake when nitrate supply is restricted to only part of the root system, J. Experiment. Bot., 26, 79-90, 1975.

Drew, M. C., Saker, L. R., and Ashley, T. W.: Nutrient supply and the growth of the seminal root system in barley. I. The effect of nitrate concentration on the growth of axes and laterals, J. Experiment. Bot., 24, 1189-1202, 1973.

Engineer, C. B. and Kranz, R. G.: Reciprocal leaf and root expression of AtAmt1.1 and root architectural changes in response to nitrogen starvation, Plant Physiol., 143, 236-250, 2007.

Fitter, A. H.: An architectural approach to the comparative ecology of plant root systems, New Phytologist, 106, 61-77, 1987.

Foehse, D. and Jungk, A.: Influence of phosphate and nitrate supply on root hair formation of rape, spinach and tomato plants, Plant Soil, 74, 359-368, 1983.

Forde, B. G.: Local and long-range signaling pathways regulating plant responses to nitrate, Ann. Rev. Plant Biol., 53, 203-224, 2002.

Forde, B. G. and Lorenzo, H.: The nutritional control of root development, Plant Soil, 232, 51-68, 2001.

Foster, R. C.: Microenvironments of soil microorganisms, Biol. Fert. Soils, 6, 189-203, 1988.

Ghidey, F. and Alberts, E. E.: Plant root effects on soil erodibility, splash detachment, soil strength,and aggregate stability, Trans. Am. Soc. Agr. Eng., 40, 129-135, 1997.
Gilroy, S. and Jones, D. L.: Through form to function: root hair development and nutrient uptake, Trends Plant Sci., 2, 56-60, 2000.

Granato, T. C. and Raper Jr., D.: Proliferation of maize (Zea mays L.) roots in response to localized supply of nitrate, J. Experiment. Bot., 40, 263-275, 1989.

Guerrero-Campo, J., Palacio, S., Pérez-Rontomé, C., and Montserrat-Martí, G.: Effect of root system morphology on root-sprouting and shoot-rooting abilities in 123 plant species from eroded lands in North-east Spain, Ann. Botany, 98, 439-447, 2006.

Gyssels, G. and Poesen, J.: The importance of plant root characteristics in controlling concentrated flow erosion rates, Earth Surf. Proc. Landf., 28, 371-384, 2003.

Gyssels, G., Poesen, J., Bochet, E., and Li, Y.: Impact of plant roots on the resistance of soils to erosion by water: a review, Progr. Phys. Geogr., 29, 189-217, 2005.

Hales, T. C., Ford, C. R., Hwang, T., Vose, J. M., and Band, L. E.: Topographic and ecological controls on root reinforcement, J. Geophys. Res., 114, 1-17. 2009.

Hallett, P. D., Gordon, D. C., and Bengough, A. G.: Plant influence on rhizosphere hydraulic properties: direct measurements using a miniaturized infiltrometer, New Phytologist, 157, 597603, 2003.

Hathaway, R. L. and Penny, D.: Root strength in some populus and salix clones, New Zealand J. Botany, 13, 333-344, 1975.

Haynes, R. J. and Beare, M. H.: Influence of six crop species on aggregate stability and some labile organic matter fractions, Soil Biol. Biochem., 29, 1647-1653, 1997.

Hochholdinger, F., Woll, K., Sauer, M., and Dembinsky, D.: Genetic dissection of root formation in Maize (Z. mays) reveals root-type specific developmental programmes, Ann. Botany, 93, 359-368, 2004.

Hodge, A.: Plastic plants and patchy soils, J. Experiment. Bot., 57, 401-411, 2006.

Jankauskas, B., Jankauskiene, G., and Fullen, M. A.: Soil erosion changes in the physical properties of Lithuanian Eutric Albeluvisols under different land use systems, Acta Agricult. Scandinavian Sect. B, 58, 66-76, 2008.

Jin, K., Shen, J., Ashton, R. W., White, R. P., Dodd, I. C., Parry, M. A. J., and Whalley, W. R.: Wheat root growth responses to horizontal stratification of fertiliser in a water-limited environment, Plant Soil, 386, 77-88, 2015.

Jing, J., Rui, Y., Zhang, F., Rengel, Z., and Shen, J.: Localized application of phosphorus and ammonium improves growth of maize seedlings by stimulating root proliferation and rhizosphere acidification, Field Crop. Res., 119, 355-364, 2010.

Jones, B. and Ljung, K.: Subterranean space exploration: the development of root system architecture, Current Opin. Plant Biol., 15, 97-102, 2012.

Knapen, A., Poesen, J., Govers, G., Gyssels, G., and Nachtergaele, J.: Resistance of soils to concentrated flow erosion: A review, Earth-Sci. Rev., 80, 75-109, 2007.

Lal, R.: Soil degradation by erosion, Land Degrad. Dev., 12, 519539, 2001.

Lal, R.: Managing soils for a warming earth in a food-insecure and energy-starved world, J. Plant Nutr. Soil Sci., 173, 4-15, 2010. 
Li, P. and Li, Z.: Soil reinforcement by a root system and its effects on sediment yield in response to concentrated flow in the loess plateau, Agr. Sci., 2, 86-93, 2011.

Li, Y., Zhu, X.-M., and Tian, J.-Y.L Effectiveness of plant roots to increase the anti-scourability of soil on the Loess Plateau, Chinese Sci. Bull., 36, 2077-2082, 1991.

Linkohr, B. I., Williamson, L. C., Fitter, A. H., and Leyser, O.: Nitrate and phosphate availability and distribution have different effects on root system architecture of Arabidopsis, Plant Journal, 29, 751-760, 2002.

Loades, K. W., Bengough, A. G., Bransby, M. F., and Hallet, P. D.: Plant density influence on fibrous root reinforcement of soils, Ecol. Eng., 36, 276-284, 2010.

López-Bucio, J., Cruz-Ramírez, A., and Estrella-Herrera, L.: The role of nutrient availability in regulating root architecture, Curr. Opin. Plant Biol., 6, 280-287, 2003.

Lynch, J. P. and Brown, K. M.: New roots for agriculture: exploiting the root phenome, Philos. Trans. Roy. Soc. B, 367, 1598-1604, 2012.

Macleod, C. J. A., Binley, A., Hawkins, S. L., Humphreys, M. W., Turner, L. B., Whalley, W. R., and Haygarth, P. M.: Genetically modified hydrographs: what can grass genetics do for temperate catchment hydrology?, Hydrol. Process., 21, 2217-2221, 2007.

Malamy, J. E.: Intrinsic and environmental response pathways that regulate root system architecture, Plant, Cell Environ., 28, 6777, 2005.

Mamo, M. and Bubenzer, G. D.: Detachment rate, soil erodibility and soil strength as influenced by living plant roots: Part II. Field study, Am. Soc. Agr. Eng., 44, 1175-1181, 2001a.

Mamo, M. and Bubenzer, G. D.: Detachment rate, soil erodibility and soil strength as influenced by living plant roots: Part I. Laboratory study, Am. Soc. Agr. Eng., 44, 1167-1174, 2001 b.

McCully, M. E.: Roots in soil: unearthing the complexities of roots and their rhizospheres, Ann. Rev. Plant Phys., 50, 695-718, 1999.

Meek, B. D., Rechel, E. A., Carter, L. M., and De Tar, W. R.: Changes in infiltration under alfalfa as influenced by time and wheel traffic, Soil Sci. Soc. Am. J., 53, 238-241, 1989.

Mitchell, A. R., Ellsworth, T. R., and Meek, B. D.: Effects of root systems on preferential flow in swelling soils, Communication in Soil Science and Plant Analysis, 26, 2655-2666, 1995.

Morel, J. L., Habib, L., Plantureux, S., and Guckert, A.: Influence of maize root mucilage on soil aggregate stability, Plant Soil, 136, 111-119, 1991.

Moreno-Espíndola, I. P., Rivera-Becerril, F., De Jésus FerreraGuerrero, M., and De Léon-González, F.: Role of root-hairs and hyphae in adhesion of sand particles, Soil Biol. Biochem., 39, 2520-2526, 2007.

Morgan, R. P. C.: Soil Erosion \& Conservation, 2nd Edn., Longman, Harlow, Uk, 1986.

Morgan, R. P. C., Quinton, J. N., and Edwards, J.: 3.05 Vegetation strategies for combating desertification. MEDALUS II Project 3 Managing Desertification. Contract EV5V-CT92-0165, Final Report covering the period 1 January 1991 to 30 September 1995.

Müller, M. and Schmidt, W.: Environmentally induced plasticity of root hair development in Arabidopsis, Plant Physiol., 134, 409419, 2004.
Oades, J. M.: Soil organic matter and structural stability: mechanisms and implications for management, Plant Soil, 76, 319-337, 1984.

Paterson, E., Sim, A., Standing, D., Dorward, M., and McDonald, A. J. S.: Root exudation from Hordeum vulgare in response to localized nitrate supply. J. Experiment. Bot., 57, 2413-2420, 2006.

Pierret, A., Latchackak, K., Chathanvongsa, P., Sengtaheuanghoung, O., and Valentin, C.: Interactions between root growth, slopes and soil detachment depending on land use: a case study of a small mountain catchment in Northern Laos, Plant Soil, 301, 51-64, 2007.

Pimentel, D.: Soil erosion: a food and environmental threat, Environ. Develop. Sustain., 8, 119-137, 2006.

Pimentel, D. and Kounang, N.: Ecology of soil erosion in ecosystems, Ecosystems, 1, 416-426, 1998.

Pohl, M., Alig, D., Körner, C., and Rixen, C.: Higher plant diversity enhances soil stability in disturbed alpine ecosystems, Plant Soil, 324, 91-102, 2009.

Pojasok, T. and Kay, B. D.: Effect of root exudates from corn and bromegrass on soil structural stability, Can. J. Soil Sci., 70, 351$362,1990$.

Posthumus, H., Deeks, L. K., Rickson, R. J., and Quinton, J. N.: Costs and benefits of erosion control measures in the UK, Soil Use Manage., doi:10.1111/sum.12057, 2013.

Prosser, I. P., Dietrich, W. E., and Stevenson, J.: Flow resistance and sediment transport by concentrated overland flow in a grassland valley, Geomorphology, 13, 71-86, 1995.

Puigdefábregas, J.: The role of vegetation patterns in structuring runoff and sediment fluxes in drylands, Earth Surf. Proc. Landf., 30, 133-147, 2005.

Quinton, J. N., Edwards, G. M., and Morgan, R. P. C.: The influence of vegetation species and plant properties on runoff and soil erosion: results from a rainfall simulation study in south east Spain, Soil Use Manage., 13, 143-148, 1997.

Quinton, J. N., Morgan, R. P. C., Archer, N. A., Hall, G. M., and Green, A.: Bioengineering principles and desertification mitigation, in: Mediterranean desertification, A mosaic of processes and responses, edited by: Brandt, C. J., Geeson, N. A., and Thornes, J. B., John Wiley and Sons, Chichester, 93-105, 2002.

Reubens, B., Poesen, J., Danjon, F., Geudens, G., and Muys, B.: The role of fine and coarse roots in shallow slope stability and soil erosion control with a focus on root system architecture: a review, Trees, 21, 385-402, 2007.

Rilling, M. C., Wright, S. F., and Eviner, V. T.: The role of arbuscular mycorrhizal fungi and glomalin in soil aggregation: comparing effects of five plant species, Plant Soil, 238, 325-333, 2002.

Robinson, D.: The response of plants to non-uniformus supplies of nutrients, New Phytologist, 127, 635-674, 1994.

Robinson, D.: Root proliferation, nitrate inflow and their carbon costs during nitrogen capture by competing plants in patchy soil, Plant Soil, 232, 41-50, 2001.

Roycewicz, P. S. and Malamy, J. E.: Cell wall properties play an important role in the emergence of lateral root primordia from the parent root, J. Experiment. Bot., 65, 2057-2069, 2014.

Sattelmacher, B., Gerendas, J., Thoms, K., Brück, H., and Bagdady, N. H.: Interaction between root growth and mineral nutrition, Environ. Experiment. Bot., 33, 63-73, 1993.

Sharma, B. R. and Chaudhary, T. N.: Wheat root growth, grain yield and water uptake as influenced by soil water regime and depth of 
nitrogen placement in a loamy sand soil, Agr. Water Manage., 6, 365-373, 1983 .

Smucker, A. J. M.: Soil environmental modifications of root dynamics and measurement, Ann. Rev. Phytopathol., 31, 191-216, 1993.

Stocking, M. and Elwell, H.: Vegetation and erosion: A review, Scottish Geogr. Mag., 92, 4-16, 1976.

Stokes, A., Atger, C., Bengough, A. G., Fourcaud, T., and Sidle, R. C.: Desirable plant root traits for protecting natural and engineered slopes against landslides, Plant Soil, 324, 1-30, 2009.

Tengbeh, G. T.: The effect of grass roots on shear strength variations with moisture content, Soil Technol., 6, 287-295, 1993.

Trimble, S. W. and Mendel, A. C.: The cow as a geomorphic agent - a critical review, Geomorphology, 13, 233-253, 1995.

Vásquez-Méndez, R., Ventura-Ramos, E., Oleschko, K., Hernández-Sandoval, L., Parrot, J.-F., and Nearing, M. A.: Soil erosion and runoff in different vegetation patches from semiarid Central Mexico, Catena, 80, 162-169, 2010.

Waldron, L. J.: Shear resistance of root-permeated homogenous and stratified soil, Soil Sci. Soc. Am. J., 41, 843-849, 1977.

Walker, T. S., Harsh, P. B., Grotewold, E., and Vivanco, J. M.: Root exudates and rhizosphere biology, Plant Physiol., 132, 44-51, 2003.
Watt, M., McCully, M. E., and Canny, M. J.: Formation and stabilization of rhizosheats of Z. mays L., Plant Physiol., 106, 179186, 1994.

Wenzel, W. W.: Rhizosphere processes and management in plantassisted bioremediation (phytoremediation) of soils, Plant Soil, 321, 385-408, 2009.

Zhang, H. and Forde, B. G.: An Arabidopsis MADS box gene that controls nutrient-induced changes in root architecture, Science, 279, 407-409, 1998.

Zhao, G., Mu, X., Wen, Z., Wang, F., and Gao, P.: Soil erosion, conservation, and eco-environment changes in the loess plateau of china, Land Degrad. Develop., 24, 499-510, 2013.

Zhou, Z. C. and Shangguan, Z. P.: The effects of ryegrass roots and shoots on loess erosion under simulated rainfall, Catena, 70, 350-355, 2007.

Zhu, J., Kaeppler, S., and Lynch, J. P.: Mapping of QTLs for lateral root branching and length in maize (Zea mays L.) under differential phosphorus supply, Theor. Appl. Genet., 111, 688-695, 2005. 